\title{
The poetic structure and strategy of Psalm 79
}

Phil J Botha

(University of Pretoria)

\section{ABSTRACT \\ The poetic structure and strategy of Psalm 79}

This paper endeavours to analyse Psalm 79 as a poetic composition and an ideological document. From the analysis, it seems that the psalm primarily served a Judaean community of believers as a means of coping with their feelings of indignation, shame, and frustration some time after the destruction of the temple in Jerusalem. The argument used is that Yahweh's efforts to exact punishment from his people for their contravening stipulations of the covenant have become detrimental to his honour. It suggests that it is time for Yahweh to act on behalf of his honour. The psalm simultaneously seems to have served as a confession of the community's faith that Yahweh can and will intervene on their behalf.

\section{INTRODUCTION}

Some of the most important aspects of Psalm 79 have been overlooked for a long time. Since the time of Hermann Gunkel, interpreters have been looking almost exclusively at the Gattung ${ }^{1}$ and possible Sitze-imLeben $^{2}$ of this psalm as keys to unlock the meaning of the text. I would like to suggest that the textual strategy of the psalm rests on its poetic structure, its intertextual relationship to other parts of the Hebrew Bible, and especially on the social values reflected in it. If the social

1 Gunkel (Gunkel-Begrich [1933] 1985:117) has no hesitation in assigning this psalm to the Gattung 'Klagelieder des Volkes'. He even calls it 'das Muster eines Volksklageliedes’ (Gunkel [1929] 1986:348). Mowinckel (1962:194) lists Ps 79 as one of the 'unquestionably communal or national laments'.

2 According to Gunkel (Gunkel-Begrich [1933] 1985:117), the usual Sitz of such psalms was 'das große Klagefest, das die Gemeinde bei allgemeinen Nöten hie und da zu halten pflegt'. Weiser (1975:544) notes that it was used in late Judaism as a prayer on the anniversaries of the destruction of the temple by the Babylonians as well as that by the Romans. He also notes (ibid.) the probable use of the psalm in the times of the Maccabees. 
aspects of Psalm 79 are taken into account systematically, it becomes clear that the psalm primarily served a Judaean community of believers as a means of coping with their feelings of indignation, shame, and frustration some years after the destruction of the temple in Jerusalem ${ }^{3}$. As it gave them the opportunity to voice these feelings before Yahweh, it simultaneously served as a confession of their faith that Yahweh could and would intervene on their behalf. Viewed from a socialscientific perspective ${ }^{4}$, it seems unfair to speak of 'a spirit of wild vengefulness' in this psalm as one that contributes 'very little to religious understanding, 5 .

The most important social values that are visible in Psalm 79 and that served as conditioning factors in the production of the text are those of honour and shame. These values are evident in the expressed need for the restoration of the honour of Yahweh and (consequently) that of his people and in the need to experience a visible intervention by Yahweh ${ }^{6}$. By intervening, Yahweh's role as superior patron deity who grants honour and extends mercy, justice, and

3 As Gunkel has noted (Gunkel-Begich [1933] 1985:139), it is extremely difficult to pinpoint the date of origin of the psalm. According to him, it could be from the time of Ezra to the time of Alexander the Great. There is no suggestion that the psalmist actually witnessed the siege and fall of Jerusalem as Terrien (2003:572) thinks. The style is suggestive of a date later than the exile (Van der Ploeg 1974:38). On the other hand, when 1 Maccabees was written, the psalm was already considered to be Scripture (De Liagre Böhl \& Gemser 1968:142).

4 A social-scientific investigation of a biblical text 'has as its goal the understanding of a text, its genre, content, structure, meaning, and rhetorical strategy as a vehicle of meaningful persuasive discourse in its original historical, social, and cultural context and as a medium of social interaction' (Elliott 1993:69).

5 Kittel (1922:268) speaks of 'der... Geist wilder Rachgier'. He also says 'Religiös hat das Lied uns damit wenig zu sagen'. It is with greater insight that Valeton (1913:48) writes that 'avenge' here implies 'the upholding of justice and a display of who God is' ('handhaving van recht, en een laten zien, wie God is'). Cf. also Leupold's criticism of Kittel (Leupold 1977:574).

6 Similar to that at the exodus. Cf. the phrase 'according to the power of your arm' in v.11b. 
retribution and who guarantees the preservation of holiness and purity would be recognised by everyone in the world.

In order to understand the social values and the intertextual relationship of the psalm with other texts, its stichometric, strophic, and poetic structure must be investigated first.

\section{STICHOMETRIC ANALYSIS}

In the following analysis, the psalm's possible segmentation is represented with Arabic numbers to the left of the Hebrew text for verse lines $(1,2$, etc.), capital Roman letters to the left of that for the strophes (A, B, etc.), and Roman numerals to the extreme left (I, II, etc.) for the stanzas. Parallelisms and chiasms are marked in the translation.

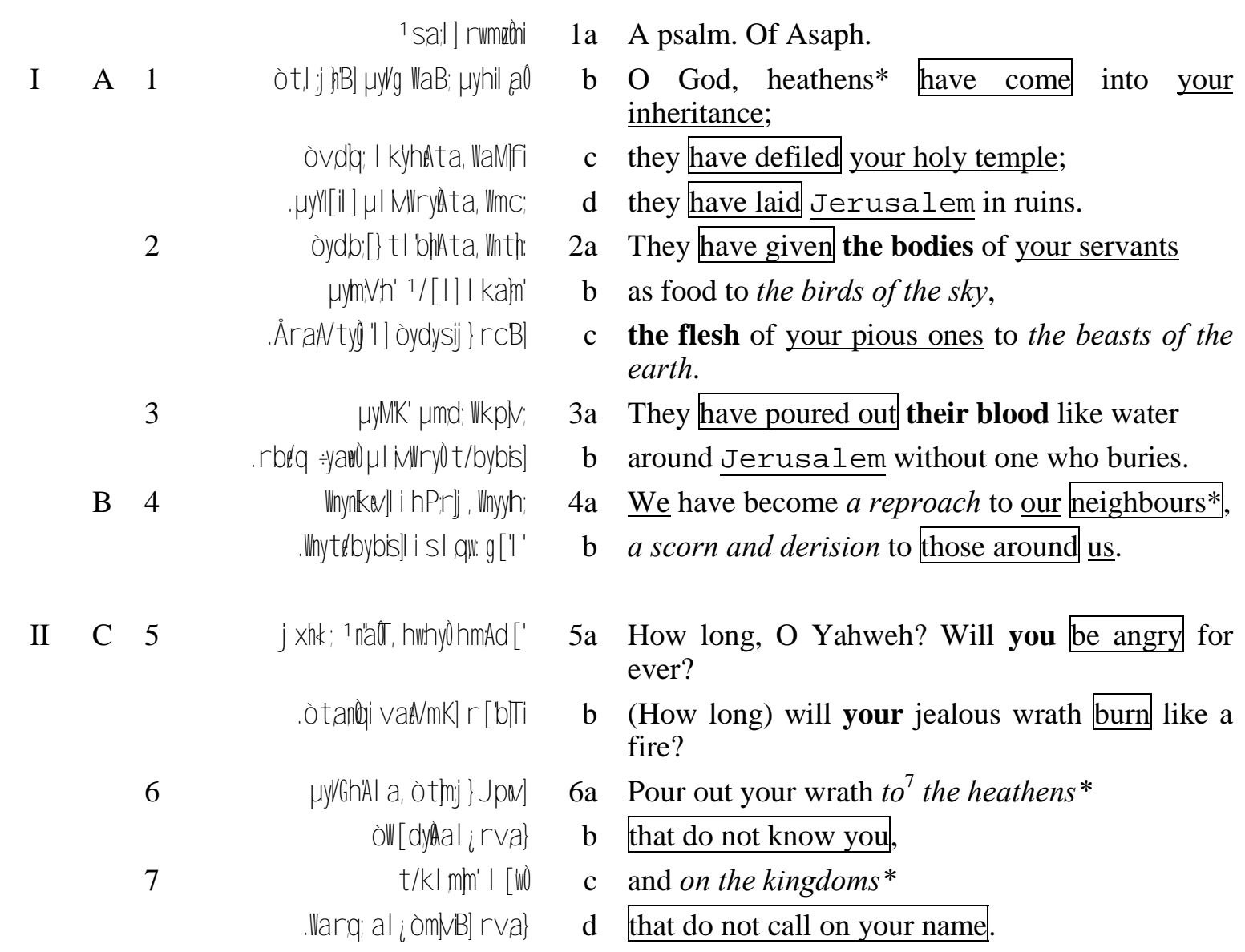

\footnotetext{
7 The use of 'pour out' with 2 is well attested, especially in Leviticus. Since it is the more difficult reading and since the parallel phrase has על probably be retained.
} 


\begin{tabular}{|c|c|c|c|c|c|}
\hline & & 8 & bqb pyat a, I ka; ; YKi & $7 \mathrm{a}$ & For they have devoured Jacob, \\
\hline & $\mathrm{D}$ & 9 & 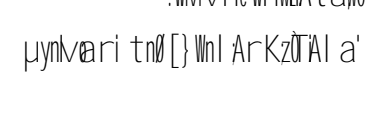 & $8 a$ & $\begin{array}{l}\text { Do not remember against us the sins of our } \\
\text { ancestors; }\end{array}$ \\
\hline & & & 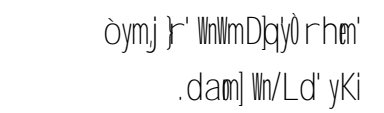 & $\begin{array}{l}\mathrm{b} \\
\mathrm{c}\end{array}$ & $\begin{array}{l}\text { let your compassion meet us speedily, } \\
\text { for we are very weak. }\end{array}$ \\
\hline & & 10 & $\begin{array}{l}\text { Wh[ e yl yh e e ÔWh ED; } \\
\text { o my Ad / L K ] r b DAl [' }\end{array}$ & $\begin{array}{r}9 a \\
b\end{array}$ & $\begin{array}{l}\text { Help us, O God of our salvation, } \\
\text { for the sake of the glory of your name; }\end{array}$ \\
\hline & & 11 & 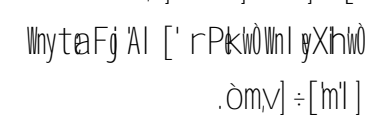 & $\begin{array}{l}\mathrm{c} \\
\mathrm{d}\end{array}$ & $\begin{array}{l}\text { and deliver us and forgive our sins, } \\
\text { for the sake of your name! }\end{array}$ \\
\hline III & $\mathrm{E}$ & 12 & 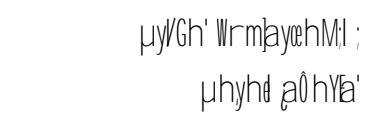 & $\begin{array}{r}10 \mathrm{a} \\
\mathrm{b}\end{array}$ & $\begin{array}{l}\text { Why should the heathens* say: } \\
\text { 'Where is their god?' }\end{array}$ \\
\hline & & 13 & Whyngl e ] ] yyC(B' [ d Wy & c & $\begin{array}{l}\text { Let it be known among the heathens* before our } \\
\text { eyes }\end{array}$ \\
\hline & & & 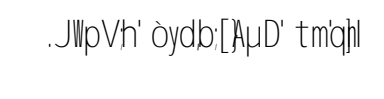 & d & $\begin{array}{l}\text { the avenging of the outpoured blood of your } \\
\text { servants. }\end{array}$ \\
\hline & $\mathrm{F}$ & 14 & rysá; t ghì, ò ynsl ] a /b T; & $11 \mathrm{a}$ & $\begin{array}{l}\text { Let the groaning of the prisoner come before } \\
\text { you; }\end{array}$ \\
\hline & & & $\dot{o}[$ lyr zol d gष] & $\mathrm{b}$ & according to the greatness of your arm, \\
\hline & & & .ht Umt ]ynB]r t th & c & preserve $^{8}$ those destined to die! \\
\hline & & 15 & 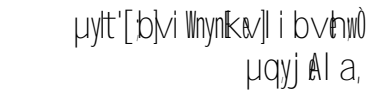 & $12 \mathrm{a}$ & $\begin{array}{l}\text { And return to our neighbours* sevenfold in } \\
\text { their bosom }\end{array}$ \\
\hline & & & 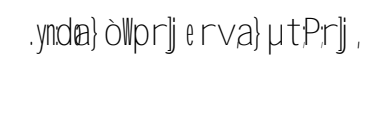 & $\mathrm{b}$ & $\begin{array}{l}\text { their reproach with which they have reproached } \\
\text { you, O Lord! }\end{array}$ \\
\hline IV & G & 16 & 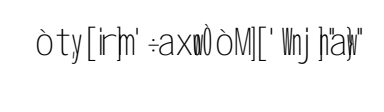 & $13 a$ & $\begin{array}{l}\text { But }^{9} \text { we, your people and the flock of your } \\
\text { pasture, }\end{array}$ \\
\hline & & & $\mu l \|[\mid] \dot{o} L] h d / n$ & $\mathrm{~b}$ & will praise you forever; \\
\hline & & 17 & $r d a r d b]$ & c & from generation to generation \\
\hline & & & . òt LhTाr Pshó & $\mathrm{d}$ & we will retell your glory. \\
\hline
\end{tabular}

8 The suggestion to change the form to a Hiph'il imperative of ('ותר ('let loose') is not compelling, since the text (from יתר) makes good sense.

9 Many English translations (KJV, NIB, NAU, RSV, etc.) translate this as a consequence of the previous verse ("So..." or “Then...”). German and Dutch translations, on the other hand, in general interpret the waw as adversative. The waw is seen here as being adversative to the rest of the psalm, therefore it constitutes a new stanza. 
they entered Jerusalem after having besieged it for eighteen months ${ }^{11}$. Verse 4 forms a different strophe (since it introduces a new subject), but is still part of the same stanza, because it describes the result of those actions of the Babylonians, namely the neighbouring nations' mocking and deriding of them.

\begin{tabular}{|c|c|c|c|c|c|}
\hline $\begin{array}{l}\text { Stan } \\
\text { za }\end{array}$ & $\begin{array}{l}\text { Stroph } \\
\text { e }\end{array}$ & $\begin{array}{l}\text { Verse } \\
\text { lines }\end{array}$ & $\begin{array}{l}\text { Verse } \\
\text { s }\end{array}$ & Themes of strophes & Themes of stanzas \\
\hline \multirow[t]{2}{*}{ I } & A & $1-3$ & $1-3$ & $\begin{array}{l}\text { The heathens have } \\
\text { defiled your sanctuary. }\end{array}$ & \multirow{2}{*}{$\begin{array}{l}\text { Your honour has } \\
\text { been tarnished. }\end{array}$} \\
\hline & B & 4 & 4 & $\begin{array}{l}\text { We have become a } \\
\text { reproach. }\end{array}$ & \\
\hline \multirow[t]{2}{*}{ II } & $\mathrm{C}$ & $5-8$ & $5-7$ & $\begin{array}{l}\text { Don't be angry with us, but } \\
\text { with them! }\end{array}$ & \multirow{2}{*}{$\begin{array}{l}\text { Forgive us and } \\
\text { redeem your honour. }\end{array}$} \\
\hline & $\mathrm{D}$ & $9-11$ & $8-9$ & $\begin{array}{l}\text { Forgive and help us for the } \\
\text { sake of your honour! }\end{array}$ & \\
\hline \multirow[t]{2}{*}{ III } & $\mathrm{E}$ & $12-13$ & 10 & $\begin{array}{l}\text { Don't let the heathens taunt } \\
\text { you; avenge your servants! }\end{array}$ & \multirow{2}{*}{$\begin{array}{l}\text { Save us and punish } \\
\text { those who mock you. }\end{array}$} \\
\hline & $\mathrm{F}$ & $14-15$ & $11-12$ & $\begin{array}{l}\text { Save us and punish our } \\
\text { neighbours who mock us! }\end{array}$ & \\
\hline IV & G & $16-17$ & 13 & We will praise you for ever. & $\begin{array}{l}\text { We will praise you } \\
\text { forever. }\end{array}$ \\
\hline
\end{tabular}

10 The present analysis differs only slightly from that of Fokkelman (2000:229230; 440). The demarcation of the stichs ('cola', as Fokkelman calls it) and verse lines are the same. He also sees seven strophes in the psalm. They coincide with the present demarcation of strophes, with the exception that verse 5 is linked to verse 4 to form the second strophe. By doing so, he ignores the demarcating question in verse 5 , while he uses this as a principle to identify the beginning of a new strophe in verse 10 (Fokkelman 2000:229). According to him, the second stanza thus begins at verse 6 . He also considers the last strophe to be part of the third stanza rather than to constitute a fourth one on its own.

11 Gunkel ([1929] 1986:349-350) argues from the absence of comments on a war, a siege, a king, a fire in the temple, or the exile of a people that the poem cannot refer to the catastrophe of 586 B.C. However, if the poem was written for use many years after these events, its silence on these matters cannot be conclusive. See also Kraus' (1989:134) criticism of these objections and his arguments that it does refer to 587/6. It seems that incidents related to the shaming of Yahweh and his people have been selected and lifted out by the poet (so also Kraus 1989:135). 


\section{Table 1: The strophic structure of Psalm 79}

Stanza II comprises verses 5-9. In its first strophe (C, verses 5-7), Yahweh is asked to pour out his wrath on those peoples who made and still make the Judaeans suffer rather than on them. The second strophe of this stanza comprises verses 8-9. In it, Yahweh is asked to forgive his people and help them for the sake of his name, thus his honour. Stanza III similarly asks Yahweh to save his people and punish those who mock him and his people. Strophe E (verse 10) and strophe F (verses 11 and 12) form a chiasmus, since the taunts to which verse 12b refers are quoted in verse 10ab. The reference to the 'outpoured blood' in verse $10 \mathrm{~d}$, on the other hand, forms a parallel to the 'groaning of the prisoner' in verse 11a. Finally, stanza IV contains only one strophe (G, verse 13) with its two chiastic verse lines. It consists of a double assurance that the people of Yahweh will praise him forever.

The boundaries between the stanzas become evident when the internal cohesion of each stanza in terms of subjects and objects, semantic fields, and parallels and chiasms are studied. However, the repetition of key words and the use of particular stylistic devices also serve to demarcate units of text ${ }^{12}$. The rhetorical questions in verse $5^{13}$ and the direct speech quoted in verse 10 are examples. The stanzas are also demarcated with the help of references to God: stanza I begins with the word $\mu$ yhl a; stanza II contains in its first hemistich a reference to hwh y; stanza III has $\mu h y h l a$ in its first verse line and it ends with a final ynd a at the end of verse line $15 .{ }^{14}$ The word $\mu$ yhl a , it must be admitted,

12 Cf. Wendland (1998:127): Discourse boundaries can be marked by figures of speech, rhetorical questions, shifts in word order, emphatic utterance, and direct speech.

13 Kraus (1989:135) remarks that these questions usually occur in the transition from a complaint to a petition within prayer songs.

14 Briggs \& Briggs (1925:200-201) consider $\mu$ yhl a in v.1 'a gl. not required for sense or measure'. In v.5, יהוה: is similarly treated as 'evidently a gl.', since it could not be part of the Elohistic version. It must be said that Briggs \& Briggs' reconstructed version of the psalm, stripped of all 'insertions' and 'glosses', shows little resemblance to the psalm analysed here. They regard its final form as 'a mosaic' constructed by a Maccabean editor for religious use on the day commemorating the destruction of the temple by Antiochus (Briggs \& Briggs1925:197-198). 
also occurs in verse line 10 (v.9ab), but in this instance it does not seem to coincide with the beginning or end of a stanza.

The 17 verse lines contain numerous internal or external parallels, of which three also constitute chiasms: the parallel elements in verse line 8 form a chiasmus; the four verse lines of stanza III are arranged chiastically; and the four hemistichs of verse lines 16 and 17 are also arranged chiastically. The parallels and chiasms serve to demarcate verse lines, strophes, and stanzas. It is significant that stanzas I, II, and III all begin with a reference to the heathens, while stanzas I and III end with references to the neighbouring nations. These references also serve to demarcate the different stanzas, and they indicate the importance of social values for the understanding of the psalm. A complete list of repeated stems are given in Table 2. From this list, it becomes clear that there is a measure of symmetry in Psalm 79. The first three stanzas all contain references to God, to the heathens, and to the action of 'pouring out'. However, there is even greater correspondence between stanzas I and III. These two stanzas in addition share occurrences of the stems for 'to come, to bring', 'blood', 'reproach' and 'neighbours'. Stanzas II and III share only one other significant stem, namely the verb 'to know'. While stanza I gives a description of what had happened in the past, stanzas II and III ask Yahweh to address these injustices by inverting the status quo so that the blood of the servants of Yahweh is revenged, the reproaches are silenced, and the honour of Yahweh and his people is restored.

\begin{tabular}{|c|c|c|c|c|c|c|c|c|c|c|c|c|}
\hline \multicolumn{4}{|c|}{ I } & \multicolumn{5}{|c|}{ II } & \multicolumn{3}{|c|}{ III } & IV \\
\hline \multicolumn{3}{|c|}{ A } & \multirow{2}{*}{$\frac{B}{4}$} & \multicolumn{3}{|c|}{ C } & \multicolumn{2}{|c|}{ D } & E & \multicolumn{2}{|c|}{$\mathrm{F}$} & G \\
\hline 1 & 2 & 3 & & 5 & 6 & 7 & 8 & 9 & 10 & 11 & 12 & 13 \\
\hline$\mu$ $\mu h l_{a}$ & & & & hwhy & & & & $\mu$ yhl a & $\mu y h l a$ & & ynd a & \\
\hline a w & & & & & & & & & & a wb & & \\
\hline$\mu \mathrm{Ng}$ & & & & & $\mu \mathrm{wg}$ & & & & $\mu$ HV & & & \\
\hline$\mu$ lvwry & & $\mu l v r y$ & & & & & & & & & & \\
\hline & $d b[$ & & & & & & & & $d b[$ & & & \\
\hline & & JpV & & & JpV & & & & Jpv & & & \\
\hline & & $\mu d$ & & & & & & & $\mu d$ & & & \\
\hline & & byos & byos & & & & & & & & & \\
\hline & & & hprj & & & & & & & & hprj & \\
\hline
\end{tabular}




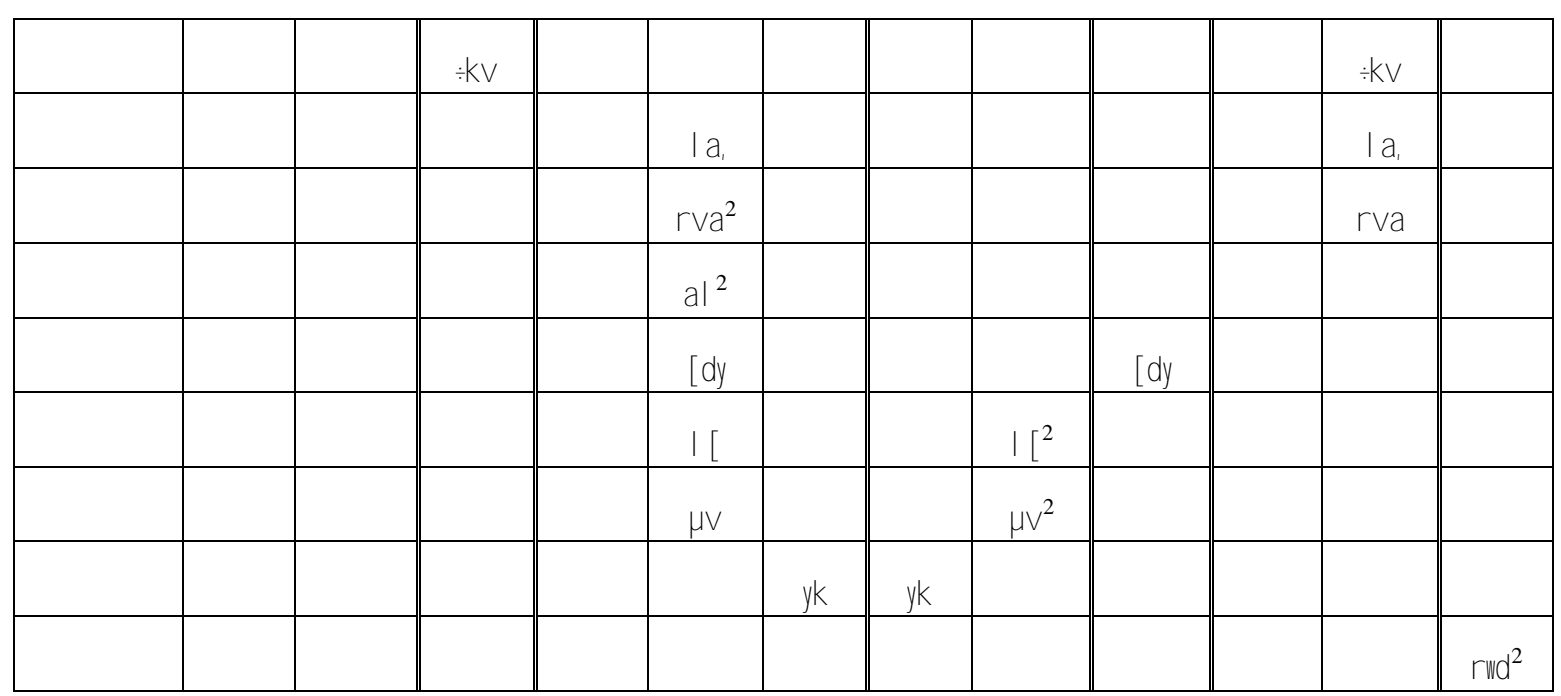

Table 2: Stems (and references to God) that are repeated in Psalm 79. The Arabic numbers refer to verses, not verse lines

An impressive number of other stylistic devices are incorporated to give the poem a coherent character. Many of the parallels already noted provide the text with instances of rhyme. Hemistichs ending in $\dot{0}$, (9x) and in Wh e(5x) abound in the psalm. Seybold (1996:314-315) has noted the alliteration in verses 2-3 and especially (of $v$ and $j$ ) in verse 12 . There are comparisons in verse lines 3 ('blood poured out like water') $)^{15}$ and 5 ('your wrath burns like a fire'), figura etymologica in verse line 15 ('the taunting with which they taunted you') and metaphors in verse lines 8 (the heathens 'devoured Jacob') and 16 ('the flock of your pasture'). Verse line 1 uses an antithesis ('defiled' your 'holy' temple) to emphasise the shocking actions of the heathens. In verse line 4, hendiadys ('derisive scorn') is used to emphasise the shame the people of Yahweh have to cope with ${ }^{16}$. The expressions 'the birds of the sky' and 'the beasts of the earth' in verse line 2 constitute a merism that serves to express the utter desecration of the bodies of Judaeans. Certain words are repeated with great effect at different focus points of the poem ('heathens', 'neighbours', 'God' in combination with

15 Watson (1986:318) calls this a 'hyperbolic simile'. The function is probably to express the invading army's complete lack of concern for human life.

16 Hendiadys is an iterative technique used to create emphasis. (Cf. Wendland 1998:130). 
'Yahweh' and 'Lord') '17. There is irony in the way in which the poet asks God to let the avenging of his servants' blood 'be known' (verse line 13) among the heathens 'who do not know' (verse line 6) him. In a similar way, it is suggested that Yahweh acts 'on behalf of his name' (verse lines 10 and 11) before the kingdoms 'that do not call' on his name (verse line 7). The references to God and the references to the 'heathens' and 'neighbours' help to demarcate the stanzas, as has been argued already. The first word of verse line 1 and the last word of verse line 15 both refer to God. This creates an inclusio, which effectively demarcates the petitionary main section of the poem from its laudatory last stanza. Repetition is used with great effect when Yahweh is asked to 'pour' his wrath 'out' to the heathens ${ }^{18}$ of whom it was said a little earlier that they 'have poured out' the blood of Yahweh's pious ones (verse lines 3 and 6). The use of the synonymous terms 'sins' ( $t$ nw in verse line 9) and 'our sins' (myt a f $j$ in verse line 11) creates an inclusio that serves to demarcate strophe $\mathrm{D}$. The expression 'those destined to die' (in verse line 14) should probably be interpreted as hyperbole ${ }^{19}$. It is intended to bring the supplication to a climax (cf. Van der Ploeg 1974:37). Fokkelman (2000:229) has also noted the wordplay between Imc ; in verse $1 \mathrm{~d}$ and WMv hein verse $7 \mathrm{~b}$; as well as between I $\mathrm{kam}$ in verse $2 \mathrm{~b}$ and $\mathrm{w} k \mathrm{a}^{20}$ in verse $7 \mathrm{a}$.

17 Gunkel (Gunkel-Begrich [1933] 1985:121-122) describes the repetition of references to God in a people's lament as a typical feature which should be seen as a relic from primitive times when many gods were worshipped and one had to ascertain that the correct deity would hear the prayer.

18 This is a metaphor that also contains metonymy ('wrath' stands for 'punishment'). Cf. Wendland (1998:138-139).

19 Verse 5, with its question of how long Yahweh will stay angry, makes it very difficult to understand the prayer as one that was composed soon after the destruction of Jerusalem (contra Weiser 1975:544). It should be kept in mind that hyperbole is an example of over-assertion, which can be described as a means value to increase honour and avoid shame. Cf. Pilch (1998:50). The question whether Yahweh will stay angry 'for ever' is another example of over-assertion.

Fokkelman (2000:230) argues for a plural form on colometric grounds. 
The poem seems to form a carefully planned and coherent whole ${ }^{21}$. The atrocities committed by the Babylonians and the shameful state of the people of Judah are related. Yahweh is then asked to forgive his people and to punish the heathens who committed these crimes and who mock him, since his honour is at stake. The poem ends with a promise that God's people will always relate his glory, perhaps suggesting that this will be so even more if he intervenes to resolve their desperate situation.

\section{INTERTEXTUAL RELATIONS}

There are some close parallels between Psalm 79 and other biblical texts, especially from Psalms and Jeremiah, but also other books from the Hebrew Bible and apocrypha. Because of the parallels, researchers have suggested that it is a late composition (Kittel 1922:267). Others think that an original lament from early exilic times was later supplied with additions to make it applicable to other situations ${ }^{22}$. Briggs \& Briggs (1925:197) regard verses 3, 9cd, 10bc, and 12 as glosses added by Maccabean editors, making the psalm appropriate to the cruelty of Antiochus. Seybold (1996:314) similarly regards the text to be 'offensichtlich prosaisiert' and supplied with 'erklärenden Zusätzen' in $1 \mathrm{~b}, 2 \mathrm{ab}, 2 \mathrm{~b}, 3 \mathrm{~b}, 10 \mathrm{aa}, 11$. There is a conspicuous difference in what Briggs \& Briggs on the one hand and Seybold on the other consider to be additions. They agree on only one element, namely part of verse 3. The reason seems to be the fact that this verse is quoted in 1 Maccabees $7: 17$. In view of the fact that the psalm seems to be a carefully planned poem, there seems to be little reason not to regard it as a unity. The parallels with other parts of Scripture seem to be rather a technique of the author, something which has been described as an 'anthological style' (Van der Ploeg 1974:38). The following table should give an idea of the extent to which Psalm 79 is reminiscent of other texts:

\footnotetext{
21 There is a definite symmetry. Table 2 shows this symmetry to a certain extent. At the same time, however, it proves that Terrien (2003:572) cannot be right when he builds up a perfect symmetry of five strophes around vv.7-9 as the 'core strophe'.

22 Kraus (1989:134), for instance, says that 'the poor condition of the text of Psalm 79 is to be traced to ... “contemporizations”.
} 


\begin{tabular}{|c|c|c|}
\hline $1 \mathrm{a}$ & \multicolumn{2}{|l|}{ A psalm. Of Asaph. } \\
\hline $\mathrm{b}$ & \multicolumn{2}{|c|}{$\begin{array}{l}\text { O God, heathens have come into your inheritance (Ps 74:2; 78:62, 71; 94:5, 14; } \\
\text { 106:5, 40); }\end{array}$} \\
\hline c & \multicolumn{2}{|c|}{ they have defiled your holy temple (Ps 5:8; 11:4; 138:2; Jonah 2:5, 8); } \\
\hline $\mathrm{d}$ & \multicolumn{2}{|l|}{ they have laid Jerusalem in ruins. ${ }^{23}$} \\
\hline 2a & They have given the bodies of your servants & \multirow{3}{*}{$\begin{array}{l}\text { Dt 28:26; Jr 7:33, 16:4, } \\
\text { 19:7, 34:20 }\end{array}$} \\
\hline $\mathrm{b}$ & as food to the birds of the sky, & \\
\hline c & the flesh of your pious ones to the beasts of the earth. & \\
\hline 3a & They have poured out their blood like water & \multirow[b]{2}{*}{1 Macc 7:17 } \\
\hline $\mathrm{b}$ & $\begin{array}{l}\text { around Jerusalem without one who buries. (2 Ki 9:10; } \\
\text { Jr 14:16) }\end{array}$ & \\
\hline 4a & We have become a reproach to our neighbours, & \multirow{2}{*}{ Ps 44:14!, 89:41, Ez 5:15 } \\
\hline $\mathrm{b}$ & a scorn and derision to those around us. & \\
\hline $5 a$ & How long, O Yahweh? Will you be angry for ever? & \multirow[b]{2}{*}{ Ps 89:47! } \\
\hline $\mathrm{b}$ & $\begin{array}{l}\text { (How long) will your jealous wrath (cf Nm 25:11; Dt } \\
\text { 29:20) burn like a fire? }\end{array}$ & \\
\hline $6 a$ & Pour out your wrath to the heathens & \multirow{6}{*}{ Jr 10:25! } \\
\hline $\mathrm{b}$ & that do not know you, & \\
\hline c & and on the kingdoms & \\
\hline d & that do not call on your name. & \\
\hline $7 a$ & For they have devoured Jacob, & \\
\hline $\mathrm{b}$ & and his habitation they laid waste. & \\
\hline $8 a$ & \multicolumn{2}{|c|}{ Do not remember against us the sins of our ancestors; ${ }^{24}$ (cf Is 65:7) } \\
\hline $\mathrm{b}$ & \multicolumn{2}{|l|}{ let your compassion meet us speedily, (cf Ps 59:11; 143:7) } \\
\hline c & \multicolumn{2}{|l|}{ for we are very weak. (Ps 142:7) } \\
\hline 9a & \multicolumn{2}{|l|}{ Help us, O God of our salvation, (Ps 85:5) } \\
\hline $\mathrm{b}$ & $\begin{array}{l}\text { for the sake of the glory of your name (cf. Ps 115:1; } \\
\text { 72:19; Dt 28:58) }\end{array}$ & \multirow[t]{2}{*}{ Jr 14:7, 21; cf Ezek 36:22 } \\
\hline c & and deliver us and forgive our sins, & \\
\hline
\end{tabular}

23 According to Briggs \& Briggs (1925:198), the expression 'laid in ruins' is dependent on Mi 1:6.

24 Briggs \& Briggs (1925:198) see a link with Dt 19:14 and Lv 26:45. 


\begin{tabular}{|c|c|c|}
\hline $\mathrm{d}$ & $\begin{array}{l}\text { for the sake of your name! (cf Ps 25:11; 31:4; } \\
143: 11 \text { ) }\end{array}$ & \\
\hline $10 \mathrm{a}$ & Why should the heathens say: & \multirow{2}{*}{$\begin{array}{l}\text { Ps } 115: 2 \text { (cf Ex 32:12), Joel } \\
\text { 2:17. }\end{array}$} \\
\hline $\mathrm{b}$ & 'Where is their god?' & \\
\hline C & \multicolumn{2}{|c|}{ Let it be known among the heathens before our eyes (cf 1 Ki 18:36) } \\
\hline $\mathrm{d}$ & \multicolumn{2}{|c|}{ the avenging of the outpoured blood of your servants. (cf Dt 32:43; Ez 25:14, 17) } \\
\hline $11 \mathrm{a}$ & Let the groaning of the prisoner come before you; & \multirow{3}{*}{ Ps $102: 21$} \\
\hline $\mathrm{b}$ & according to the greatness of your arm, (Ex 15:16) & \\
\hline C & preserve those destined to die! & \\
\hline $12 \mathrm{a}$ & $\begin{array}{l}\text { And return to our neighbours sevenfold (Gn 4:15, 24; } \\
\text { Prov 6:31) in their bosom (Jr 32:18) }\end{array}$ & \multirow{2}{*}{$\begin{array}{l}\text { Is } 65: 6 \text {, cf Neh } 3: 36(\mathrm{MT}) \text {; } \\
\text { cf. Lv 26:18, 21, 24, } 28\end{array}$} \\
\hline $\mathrm{b}$ & $\begin{array}{l}\text { their reproach with which they have reproached you, } \\
\text { O Lord! }\end{array}$ & \\
\hline $13 \mathrm{a}$ & \multicolumn{2}{|c|}{ But we, your people and the flock of your pasture, (Ps 74:1; 95:7; cf also Ps 80:1) } \\
\hline $\mathrm{b}$ & \multicolumn{2}{|l|}{ will praise you forever; (Ps 44:9) } \\
\hline C & from generation to generation & \multirow{2}{*}{$\begin{array}{l}\text { Cf Ps 45:17; 89:1; 102:13; } \\
\text { 135:13. Contrast Ps 85:5 }\end{array}$} \\
\hline $\mathrm{d}$ & we will retell your glory. & \\
\hline
\end{tabular}

Table 3: Intertextual relations of Psalm 79 to other texts in the Tenak. The underlined phrases are the elements pertinent to the texts between brackets

From this table it seems that Psalm 79 has been influenced greatly by some of the post-exilic psalms and the prophetic literature, especially the books of Isaiah and Jeremiah ${ }^{26}$. Despite the fact that some phrases in Psalm 79 seem to be direct quotations from other texts, such quotations were incorporated very skilfully and effectively into the composition. It does not distract from the coherence of the text as a

\footnotetext{
25 Briggs \& Briggs (1925:198) also refer to Ps 100:3.

26 Some of the similarities could possibly also be explained as allusions to Ps 79 in other texts. See in this regard Gosse (2004), who argues convincingly that the editors of Jeremiah have borrowed extensively from the Psalms, especially also from Ps 79. Van der Ploeg (1974:39) and Seybold (1996:314) have also argued that vv. 6-7 are quoted in Jr 10:25. Delitzsch (1871:57-58) has argued that it is the other way round (the psalmist quoting from Jeremiah), but his arguments are not conclusive. Valeton (1913:46) similarly thinks of the words as a gloss from Jeremiah that later became incorporated into the text of the psalm.
} 
new composition, but rather creates the feeling of reminiscence of other parts of Scripture and of being in line with the prophecies and prayers of the people of Judah ${ }^{27}$. The truth of this becomes even more evident when the parallels between Psalm 79 and Psalm 74 are considered. Psalm 74 is referred to only twice in Table 3, but there is a conspicuous similarity in ideas, arguments, and theology between the two psalms and consequently also in function ${ }^{28}$.

\section{THE SOCIAL DIMENSION OF PSALM 79}

Thus far, it has become sufficiently clear that the relationship between Yahweh and his people in Psalm 79 is a function of their relationship with other peoples. The relationship with Yahweh is strained because it seems to them that he is still angry with them (verse line 5) because of the sins of their ancestors (verse line 9). They want Yahweh to forgive these sins (verse line 9) and to punish the other nations instead (verse lines 6 and 7). To substantiate this request, they furnish a series of reasons:

(a) Heathens desecrated Yahweh's holy temple and have ruined the holy city (verse line 1).

(b) They committed atrocities against Yahweh's servants and pious ones (verse line 2).

(c) The Babylonians ignored human rights and defiled the land of Judah (verse lines 3 and 8). The blood that has been spilt must be avenged (verse line 13).

(d) The misfortunes suffered by the Judeans incite their neighbours to taunt and deride them (verse line 4). They mockingly ask 'where is the God of the people of Judah?' (verse line 12).

\footnotetext{
27 It is correct to describe the style of the psalm as 'anthological', but it is not less artistic because it contains numerous quotes or allusions. Cf. Van der Ploeg's (1974:38) remark: 'De psalm is anthologisch van karakter en mist de krachtige, eigen stijl van bv. Ps 78'.

28 Delitzsch (1871:56) has noted the following similarities: the question of 'how long?' (79:5 and 74:1 and 10); the use of [dwy (79:10 and 74:5); the wild animals (79:2 and 74:14 and 19); Israel as a flock of sheep (79:13 and 74:1 and 19). Both psalms refer to the destruction of the temple and show a close affinity with Jeremiah.
} 
(e) The heathens do not recognise Yahweh as supreme God and do not call on his name (verse lines 6 and 7).

(f) Yahweh's people are on the verge of dying (verse lines 9 and 14).

(g) The honour of Yahweh is at stake, since it might seem that he is not unwilling to help them, but unable to do so (verse lines 10 and 11). The nations taunt not only the people of Judah, but their God also (verse line 15). These taunts have to be avenged (verse line 15).

(h) Yahweh's people will carry on to praise him and relate his honour whether he decides to act or not (verse lines 16 and 17).

It is difficult to understand these requests fully without considering the nature of a covenantal relationship and the role played by honour and shame as sanctioning social values in such a relationship. In biblical times, every male member of society had the objective of preserving his honour and the honour of his family. This was the most important aim of social interaction. In international relations, each nation had a similar objective of increasing national honour ${ }^{29}$. Israel's claim to honour was its special relationship with Yahweh, the evidence that God was on their side (Plevnik 1998:108). If the nation prospered, their claim to worship the highest God would be substantiated. Prosperity and success would prove that Yahweh is as powerful as they claimed and that he was willing to advance their international standing. A catastrophe or calamity such as the destruction of the temple in Jerusalem could be absorbed religiously, since it could be taken as proof that Yahweh was concerned for his honour ${ }^{30}$. If Yahweh's people were disloyal to his covenant with them, concerns for purity, holiness, and justice dictated that he should react by shaming them in public ${ }^{31}$, even to the point of allowing the destruction of their capital city and his

\footnotetext{
29 As Olyan (1996:204) writes, honour 'is a commodity of value, actively sought both by deities and by human beings ... honor is meant to be recognized and acknowledged; it is very much a public phenomenon. Loss of honor or diminishment results in shame; diminishment communicates a loss of social status'.

30 That is, that he punishes them for having shamed him.

31 The correct term is 'diminishment', which results in shame. Cf. Olyan (1996:203).
} 
own temple ${ }^{32}$. At the same time, however, the desecration of his holy temple and the atrocities committed against his people could not go unpunished forever. Eventually Yahweh would have to avenge the death of his servants and to silence the derogatory remarks of their neighbours about his seeming inability to save them, since his own international honour would be at stake ${ }^{33}$.

The major concern of the author or group of authors who produced this text, therefore was the honour of Yahweh and their own national honour $^{34}$. On a personal level, honour was a core value of society. For someone with legitimate claims to honour, death was preferable to having to live in shame ${ }^{35}$. This rule applied mutatis mutandis to international relations and national religious claims ${ }^{36}$. Honour was primarily a group value (Plevnik 1998:107). The lament that heathens

32 Cf. Jr 7:1-15.
33 Cf. Nm 14:15-16. As Nötscher (1953:161-162) notes, if the avengement stays away, the people will continually be regarded as the guilty party. It is also important to note that the expectation of avengement of spilled blood has much to do with trust, a value 'that serves as a means to attaining an honorable existence' (Pilch 1998:202). It should not be described as 'vengefulness'.

34 Nötscher (1953:160) correctly defines God's honour and the continued existence of his people as the crucial issues in the psalm. He shows great insight in the importance of honour as a social value when he says that misfortune was usually regarded as a lack of righteousness, but the demise of the people of Yahweh as a lack of ability on the side of their God. He continues: 'Es ist also nicht reiner Rachedurst, der diese Sprace eingibt, es ist eine Art geistige Notwehr, die um Sein und Ehre kämpft'.

35 As Plevnik (1998:108) explains, '...where honor is the highest value, public humiliation is a fate worse than death...'

36 Gunkel (Gunkel-Begrich [1933] 1985:126) is on the wrong track when he explains the preoccupation with such matters in a psalm like Ps 79 as a result of the fact that Israel was 'politically strongly orientated' and therefore more troubled by such matters than by natural catastrophes. He continues: 'Dabei hat der stolze Jude einen lebhaften Eindruck davon, daß ihm (diese) Drangsale zur Schande gereichen'. Mowinckel (1962:197) makes a similar remark which shows a lack of understanding of honour as a core value of society: he speaks of 'the old Israelite idea that disaster and defeat mean "shame", which makes the people wince at the sneers of their neighbours'. 
have come into Yahweh's 'inheritance' and have 'defiled' his 'holy temple' refer to the social values of purity and holiness. Purity was a characteristic of someone who knew how to be clean rather than unclean and pure rather than polluted; in other words, how to maintain honour and avoid shame ${ }^{37}$. Purity and holiness are means values that serve to maintain boundary lines and thus honour. The 'inheritance' mentioned in verse $1 \mathrm{~b}$ most probably refers to the people of Judah as the nation whom Yahweh has set aside for himself ${ }^{38}$. The 'coming' of heathens 'into' Yahweh's inheritance signals the crossing of lines that rendered Yahweh's people (or land) impure. The enemy's entering into Yahweh's 'holy temple', where only pure members of his people were allowed, signals defilement (v.1c). This in turn signifies loss of honour for Yahweh, and thus also for his people. The fact that the blood of Yahweh's 'servants' and 'pious ones' were spilled and their bodies left unburied to become carrion for birds and beasts, signifies that the people for whom Yahweh was responsible as a patron were shamed severely. Such treatment had to be avenged ${ }^{39}$. For effect, the author uses emotive phrases that are meant to reflect the abhorrence of the people of Judah of what had happened to Yahweh's property ${ }^{40}$ : 'your inheritance', 'defiled your holy temple', 'your servants', 'your pious ones', 'poured out like water'. Figures of speech such as antithesis ('defiled' and 'holy'), merism ('heaven' and 'earth'), comparison ('poured out like water') and hendiadys ('mockery and derision') are all used to heighten the degree of indignation, shame, and frustration voiced by the community of believers ${ }^{41}$.

\footnotetext{
37 Pilch (1998:170).

38 The form $|\mathrm{t}| \mathrm{j}$ n does refer to the sanctuary in Ex 15:17, but in the majority of occurrences of the form when the suffix refers to Yahweh, the people of Yahweh is meant (cf. Ps 28:9; 33:12; 68:10; 74:2; 94:5; 106:5; Isa 63:17; Joel 2:17; Mic $7: 14)$. Anderson (1981:577) thinks the land of Israel or Jerusalem is more possible. Gunkel ([1929] 1986:350) thinks that people, land, and sanctuary are meant.

39 Cf. Dt 32:43; cf. also Gerleman (1971:448-451) and Malina (1998:151-155).

40 Cf. Gunkel's remarks on this as a standard feature of a lament of the people (Gunkel-Begrich [1933] 1985:129).
}

41 Gunkel (Gunkel-Begrich [1933] 1985:125) notes that the lament was formulated in such a way, 'daß daraus Gedanken, die Gott zur Hilfeleistung und 
The social values of honour and shame are explicitly mentioned in some verses. The community uses words such as 'a taunt' and 'a mockery and derision' in verse 4 . The last pair could probably be understood as hendiadys and represented with 'a mocking derision'. With these words they describe the way in which their 'neighbours' and 'those around' them view them. It should be kept in mind that honour was a claim to worth that was publicly acknowledged (Plevnik 1998:107). Their claim to honour as a nation or a group of believers was publicly denied and repudiated by their neighbours. The out-group includes also the 'heathens' although the term is reserved to refer to the Babylonians in verse 1 . In verse 6, the 'heathens' are described as those who 'do not know' Yahweh. The description is used in parallel with 'the kingdoms that do not call on (his) name'. It seems that more nations than the Babylonians are referred to, even when it is said that 'they have devoured Jacob' and 'laid his habitation waste'. Nations such as the Edomites could be the ones referred to $^{42}$. The Edomites were usually, however, considered as part of those who lived around them, their neighbours ${ }^{43}$. In verse 10 , the 'heathens' must refer to peoples other than the Babylonians, since these nations form part of the audience who have to take cognisance of the avenging of the blood (against the Babylonians). This verse is significant, since it once more shows the importance of spectators in the establishment, increase, or diminishment of honour. The nations should take note of Yahweh's revenge. Then they will stop mocking the people of Judah. The avenging should also take place 'before the eyes' of the people of Judah.

zum Zorn gegen seine Gegner entflammen sollen, mittelbar hervorgehen'. It seems that he did not consider the possibility that the text could also serve to help the people of Yahweh to come to terms with their situation.

42 Cf., for instance, Ps 137:7. The Edomites cried out that Jerusalem had to be torn down to its foundations.

43 Mowinckel (1962:197) identifies the 'neighbours' in general as 'the other Palestinian nations', while the 'nations' could be peoples such as those mentioned in Ps 83, viz. Edom, Moab, the Ishmaelites, Gebal, Ammon, Amalek, the inhabitants of Tyre, etc. 
The blood of Yahweh's servants should be avenged. However, what troubles the faithful even more, is the taunts they have to cope with. For that reason the taunting of Yahweh should be avenged seven times $(\mathrm{v} .12)^{44}$. This is not only for the sake of creating a climax in the psalm (so Van der Ploeg 1974:37). Some other expressions also testify to the importance of Yahweh's honour. He is asked to act 'for the sake of the glory of (his) name' and 'for the sake of (his) name' (v.10). Name replicates honour ${ }^{45}$, and the parallel in Ezekiel 36:22 clearly indicates that it is for the sake of his honour that Yahweh should act. The phrase 'according to the power of your arm' is strongly reminiscent of a text such as Exodus 15:16 and points to the reputation of Yahweh as an almighty God that has saved his people miraculously in the past. He is now asked to repeat those miracles. As the patron deity of his people, his ‘jealous wrath' (v.5b) has now been directed for too long against his covenant people. It does not serve any longer to restore the honour that has been tarnished by his people ${ }^{46}$. To keep punishing them will be detrimental to his honour in the eyes of the world ${ }^{47}$. Therefore, he is required to act in accordance with his covenantal responsibility $(\mid$ yd $\mathrm{ys} j$, v. $2^{48}$, I ymj r, v.8 and $\mu d A t m q n$, v.10; cf. v.11) rather than with his covenantal rights $\left({ }^{1} \mathrm{na}, \mathrm{Itanq}, \mathrm{v}\right.$. 5). The honour of Yahweh is mentioned finally also in verse 13. In this verse, the religious community uses covenantal terminology (such as 'your people' and

\footnotetext{
44 The parallels from Leviticus referred to in Table 3 underscore the seriousness of this transgression. 'Seven' serves as a symbol of completeness. The 'bosom' refers to the 'fold formed by one's outer garment overhanging the girdle, which served the purpose of a pocket... (it) suggests that the recompense will directly affect the guilty party' (Anderson 1981:580).

45 So also Gunkel (Gunkel-Begrich [1933] 1985:130).

46 Texts such as Dt 29:19, Is 9:6 and Ps 69:9 (and many others) indicate that hanq replicates the concern for one's own honour or that of one's patron.

47 Viewed from this perspective, it is clear that the psalm laments the state of shame more than the original occasion that caused it, namely the destruction of the city of Jerusalem.

48 The word is used to describe people who are loyal to a covenant (Pilch 1998:185). Covenant love from the side of Yahweh would necessitate the avenging of such treatment as is described here.
} 
'the flock of your pasture') to promise compliance with their covenantal responsibility in future. Their responsibility would be to 'praise' Yahweh, their patron deity, and to 'retell' his 'glory' from 'generation to generation'. Verse 13 is not to be seen as a Fremdkörper in this psalm. Although it stands on its own and might seem to be disconnected from the rest of the psalm, it has a very important function. It ends the psalm on a positive note and provides hope for the future. The role played by the social values of honour and patronage in it is similar to that in the rest of the psalm and it forms a fitting closure to the psalm as a whole.

\section{CONCLUSION: THE TEXTUAL STRATEGY AND FUNCTION OF PSALM 79}

The textual strategy of Psalm 79 is evident in its definition of an ingroup $^{49}$ and opposing out-groups ${ }^{50}$, the role accorded to the social values of honour and shame and covenant love, rights, and responsibilities. The use of literary devices, in particular the repetition of certain key-words, serves to demarcate strophes and stanzas in which the author and the community who used this psalm systematically voiced their concern for the loss of honour which they experienced. Not only was their honour affected, but the honour of Yahweh himself was also tarnished by his seeming preoccupation with exacting punishment from them for sins of their ancestors. In their view, this approach had become detrimental to Yahweh's honour in itself. It was time to think of covenantal responsibility and no longer of covenantal rights. By using descriptive language, questions (vv.5 and 10), negative and positive commands, quotes and allusions to other parts of Scripture, and an argumentative inclination, the author or authors helped the community of believers to voice their indignation, frustration, and shame; but also their faith and hope in the power and willingness of their patron God to intervene and turn the situation around. The psalm

49 Described with emotive words such as 'your inheritance', 'your servants', 'your pious ones', 'Jacob’, ‘your people', and ‘the flock of your pasture'.

50 Described with words such as 'heathens', 'our neighbours', 'those around us', 'those who do not know you', and 'those kingdoms that do not call on your name'. 
begins with a lament and ends with praise ${ }^{51}$. This is not a sign that someone has tampered with the text, but proof that it is a carefully composed and genuine reflection of the needs and hopes of a postexilic community of believers.

\section{Consulted literature}

Anderson, A A 1981. The Book of Psalms, Vol. II. Grand Rapids: Eerdmans (NCBC).

Briggs, C A \& Briggs, E G 1925. A critical and exegetical commentary on the Book of Psalms. Vol. II. Edinburgh: T \& T Clark (The International Critical Commentary).

De Liagre Böhl, F M Th \& Gemser, B 1968. De Psalmen. Tekst en uitleg. Nijkerk: Callenbach.

Delitzsch, F 1871. Kommentaar op De Psalmen. Vertaald door J. Hartog, Deel I. Utrecht: Kemink en Zoon.

Elliot, J H 1993. What is social-scientific criticism? Minneapolis: Fortress (Guides to Biblical Scholarship).

Fokkelman, J P 2000. Major poems of the Hebrew Bible. At the interface of prosody and structural analysis. Vol. II: 85 Psalms and Job 4-14. Assen: Van Gorcum (Studia Semitica Neerlandica).

Gerleman, G 1971. Article s.v. ' $\mu$ D; dām Blut' in Jenni, E \& Westermann, C (Hrsg.) 1971, Theologisches Handwörterbuch zum Alten Testament, Band I, 448-451. München: Kaiser und Zürich: Theologischer Verlag.

Gosse, B 2004. Le Psautier, Jr 9:1-8, et le livre de Jérémie. Old Testament Essays 17/1 (forthcoming).

Gunkel, H [1929] 19866. Die Psalmen. Übersetzt und erklärt. Göttingen: Vandenhoeck \& Ruprecht.

-, [1933] $1985^{4}$. Einleitung in die Psalmen. Die Gattungen der religiösen Lyrik Israels. Zu Ende geführt von J Begrich. Göttingen: Vandenhoeck \& Ruprecht.

Kittel, D R $1922^{3} \& 4$. Die Psalmen, übersetzt und erklärt. Leipzig: Deichertsche (Kommentar zum Alten Testament).

Kraus, H-J 1989. Psalms 60-150. A commentary. Translated by H C Oswald. Minneapolis: Augsburg.

Leupold, H C 1977 [1959]. Exposition of the Psalms. Herts: Evangelical Press.

51 Gunkel (Gunkel-Begrich [1933] 1985:132) would rather describe it as the typical 'Gewißheit der Erhörung' often found in laments. 
Malina, B J 1998c. Article s.v. 'Patronage' in Pilch, J J \& Malina, B J (eds) 1998, 151-155. Peabody: Hendrickson.

Mowinckel, S 1962. The Psalms in Israel's worship. Translated by D R ApThomas, Vol. I. Oxford: Blackwell.

Nötscher, F 1953. Die Psalmen. Würzburg: Echter. (Das Alte Testament.)

Olyan, S M 1996. Honor, shame, and covenant relations in Ancient Israel and its environment. $J B L$ 115(2), 201-218.

Pilch, J J 1998a Article $s v$ 'Dramatic Orientation', in Pilch, J J \& Malina, B J (eds.) 1998, 50-53. Peabody: Hendrickson.

-, 1998b Article $s$ v 'Purity', in Pilch, J J \& Malina, B J (eds.) 1998, 170-173. Peabody: Hendrickson.

-, 1998c Article $s$ v 'Steadfast Love', in Pilch, J J \& Malina, B J (eds.) 1998, 184186. Peabody: Hendrickson.

-, 1998d Article $s v$ 'Trust (Personal and Group)', in Pilch, J J \& Malina, B J (eds.) 1998, 201-204. Peabody: Hendrickson.

Pilch, J J \& Malina, B J (eds.), 1998. Handbook of Biblical social values. Peabody: Hendrickson.

Plevnik, J 1998b Article $s v$ 'Honor/Shame', in Pilch, J J \& Malina, B J (eds.) 1998, 106-115. Peabody: Hendrickson.

Seybold, K 1996. Die Psalmen. Tübingen: Mohr (Handbuch zum Alten Testament $\mathrm{I} / 15)$.

Terrien, S 2003. The Psalms. Strophic structure and theological commentary. Grand Rapids, Michigan/Cambridge, U.K.: Eerdmans (The Eerdmans Critical Commentary).

Valeton, J J P 1913. De Psalmen. Deel II, Psalm 73-150. Tweede druk, herzien door Obbink, H Th. Nijmegen: $\mathrm{H}$ ten Hoet.

Van der Ploeg, J P M 1974. Psalmen. Deel II. Roermond: J J Romen (BOT).

Watson, W G E 1986. Classical Hebrew poetry. A guide to its techniques. Sheffield: JSOT Press (JSOT Suppl. Series 26).

Weiser, A $1955^{4}$. Die Psalmen. Zweiter Teil: Psalm 61-150. Göttingen: Vandehoeck \& Ruprect (Das Alte Testament Deutsch).

-, 1975. The Psalms. A commentary. Translated by H Hartwell. London: SCM (OTL).

Wendland, E R 1998. Analyzing the Psalms. With exercises for Bible students and translators. Winona Lake: Eisenbrauns, or: Dallas: Summer Institute of Linguistics. 